Віялета Нікічюк-Пэркоўска

Беласток

\title{
Тэма вечара і ночы ў паэзіi Наталлі Арсенневай
}

Паэтычныя прыярытэты выдатнай беларускай эміграцыйнай паэтэсы Наталлі Арсенневай выявіліся ўжо на самым пачатку яе творчага шляху. У прыватнасці, праз усё жыццё яна пранесла захапленне хараством прыроды. Ужо ў рэцэнзіі на першую яе кнігу «Пад сінім небам» (1927) М. Чэмер адзначае: Наталля Арсеннева мае уусё, каб зрабічиа першарадным твориам у паэзіі, - мае глыбокі $i$ шырокі грунт пад сабой - у пачуциі спачатных, асноўных стыхіяў Жыичя $і$ Прыроды (...) Яна мае выплываючую з гэтай кройнай неразрыўнай сувязі з Прыродай $i$ мочнай у ёй апоры - магутную сілу душы $i$ бязмежна, бязмерна ўдзячную любоў да Жьиця $i$ веру да гэтае прыродыз ${ }^{1}$. Пры гэтым на працягу ўсёй паэтычнай дарогі Н. Арсенневай уласціва мілаванне, нават апалогія восені ${ }^{2}$, што дало падставы гісторыкам літаратуры назваць яе як «пясняркай прыроды», так і «паэтэсай восені».

Аднак Н. Арсенневу можна таксама лічыць, пра што сведчаць яе шматлікія вершы, паэтэсай вячэрняй napbl, незвычайнай, непаўторнай літаратурнай мастачкай ночы. Зацікаўленне гэтай тэматыкай у Арсенневай праяўляецца ўжо ў першых яе вершаваных спробах. У яе паэтычных радках з часой Першай Віленскай Беларускай гімназіі, лірыч-

1 М. Чэмер, Верная дачка Сонца $i$ «шчьрай зямелькі», «Родныя гоні». Месячнік літаратуры й культуры Заходняй Беларусі, Вільня 1927, кн. 5, с. 36.

2 Я. Чыквін, Нязменна верная жыцию (Творчасць Наталлі Арсенневай), [у:] Я. Чыквін, Па прызванні і абавязку. Літаратурна-крытыиныя артыкуль, Беласток 2005, с. 69. 
ная гераіня ляціць думкамі ў час змяркання, калі сонца кранаецца зямлі на захадзе. Гэты пейзаж захапляе яе душу:
Аджываюць нячутна жаданьні
ў гэты час, час маўклівы зьмярканьня.
Я хачу на часінку забыцца аб горы
і глядзець, як у рожавым захаду моры сонца косы бярэцца тапіць.
Я памерці хачу вось такою парою, хваляй сонца залітая ўся залатою, больш каб слова ня чуць: «Пацярпі!»3

У творах, напісаных Н. Арсенневай годам пазней, у 1921, раскрываецца прычына яе захаплення начной парой. У вершы «Ночы й думкі» паэтэса прызнаецца, што гэтая тэматыка прыцягвае яе таму, што начная пара адкрывае перад ёю свае таямніцы, вабіць сваёй прыгажосцю, захоплівае спакоем, цішынёй, але і выклікае трывогу:
Ёсьць ночы белыя, ёсьць цёмныя, глухія.
Ёсьць гаманлівыя - і ёсьць зусім ціхія.
$\mathrm{Ix}$ - больш за ўсё люблю зь лядзяным зьзяньнем зор, што на шаўкох нябёс празрысты ткуць узор.
Люблю за супакой, хоць сонны, а чаройны, люблю за сіні змрок, за смутак невыслоўны (...) (12).

Захапленне паэтэсы гэтай тэматыкай пачынаецца ў 20-ыя гады. Найбольш аднак вячэрнімі і начнымі матывамі насычана паэзія Наталлі Арсенневай 30-тых гадоў - польскага часу, хэлмна-равіцкага перыяду: «Часта ўвечары» (1930), «Тае вечар» (1932), «Калі» (1932), «Вячорная містэрыя» (1932), «Вячорныя часіны» (1933), «Ноч» (1933), «Зімовая ноч» (1935), «Месячнай ночай» (1935), «Зоры» (1935), «Асенні вечар» (1936), «Часіны творчасці» (1935), «Фэстываль» (1936), «Калі скончыцца дзень» (1936), «Вячорны абразок» (1936), «Начныя гадзіны» (1936), «Месяц» (1935), «Ноч» (1936).

Уздзеянне майклівага часу змяркання ды ночы адгукаецца у ёй шматлікімі душэўнымі пералівамі, водгукамі і асацыяцыямі. У адных

3 Н.. Арсеннева, Між берагамі. Выбар паэзіi Наталлі Арсенневай 1920-1970, Нью-Ёрк - Таронта 1979, с. 15. Далей пры спасылцы на гэтае выданне ў дужках падаецца старонка. 
вершах ноч намалявана Арсенневай як час гармоніі жыцця, дзе няма ніякіх жыццёвых турботаў і жахаў, дзе пануе адначасова цнатлівая цішыня. У другіх вершах вячэрняя пара нясе $\ddot{y}$ сабе сум, тугу i нейкі неназваны страх. У шэрагу іншых ноч спрыяе развагам над жыццём - людскім быццём-небыццём, бо ноч, як вынікае $з$ вершаў, гэта найлепшая пара для рэфлексіі, роздумаў пра агульначалавечыя ды свае праблемы. Гэта час, калі змяняецца ўспрыманне штодзённых рэчаў. I сапраўды, як адзначае даследчык Дар'юш Куляс: Noc przez swoja bezksztaltność, brak konturów, zaciemnienie rysów dnia i porządków społecznych, otwiera sie na wymiar metafizyczny ${ }^{4}$. Ноч для Арсенневай гэта асаблівы час душы, калі яшчэ больш, чым увечары, абвастраюцца ўнутраныя перажыванні, спраектаваныя паэтэсай у свет прыроды, адкрытай стыхіі. Гэтай парой чалавеку хочацца зразумеці сусветныля сумы й жалобы і самога сябе ў гэтым свеце.

Захацелася ў ночы

Ў змрок зімовы не глядзець,

А спусціўшы твар і вочы,

Ня любіць і не цярпець (30).

У начны час, як вынікае з вершаў, людская душа адрываецца ад штодзёншчыны і апынаецца перад нязведаным. Ноч дае Арсенневай магчымасць пабыць сам-насам са сваімі думкамі, сваімі ўяўленнямі і пачуццямі.

Матывы змяркання, вечару, ночы ў вершах Наталлі Арсенневай выступаюць у значнай ступені абавязковымі элементамі яе любімага восеньскага пейзажу, які вабіць вока сваёй маляўнічасцю, захоплівае гамай колераў, выклікае шматлікія пачуцці, успаміны. Ды у вершы паэтэсы ӱваходзяць таксама і вясеннія, летнія, зімовыя ночы, і кожная з іх па-свойму арыгінальная, насычаная глыбокімі перажываннямі і роздумамі аўтаркі. Аднак, як падкрэсліӱ Станіслаў Станкевіч у артыкуле "Аб беларускай літаратурнай сучаснасці у Заходняй Беларусі", (...) найбольш натхненьняў знаходзічь яна ў чароўных абразох летняе ночы. Калі беларуская вясна сваімі ласкамі $і$ магутным прылівам новага жьиция парывае за сабой уражлівую душу поэткі $i$ напайняе яе натхнёнымі ўзьлётамі $і$ няўстрыманымі парывамі, то густы змрок ночь, бляды сьвет месяча, таемнае мірганьне зораў

4 D. Kulas, Noc w kulturze - noc kultury, [w:] J. Ławski, K. Korotkich, M. Bajko, Noc. Symbol - temat - matafora. Wokól straży nocnych Bonawentury, Białystok 2011, t. I, s. 94 . 
і сіня-сівы туман, - усе гэтыля ночныля зьявы на фоне мёртвае иішыні й супакою сплятаюџь у ўвабражэньні поэткі чароўную казку, што вабіџь яе сваёй фантастычнасьию 5 . I зразумела, што ў той фантастьинай чаройнай казиы, магічнай пары пераходу дня ў ноч, у якой яна, мабыць, адчувае сябе на ўлонні роднай прыроды, Арсенневай пішацца найлепш:

Растуць у лесе вершы ўвечары...

Разьлёгся лес імхамі, плесьняю.

Іду сьцяжынкай непрыкмечанай

і цешу сэрца новай песьняю.

(...)

А ўсё ж люблю тварыць я ўвечары! (69)

У Арсеннеўскім бачанні ночы галоўную ролю адыгрывае прыгажосць начнога роднага краявіду. Для перадачы найбольш дакладнай карціны вячэрняй прасторы, начнога пейзажу ды настрою, выкліканага гэтымі з'явамі, паэтэса карыстаецца трапнымі вобразамі-дэталямі, якія ствараюць арыгінальны малюнак. Найбольш паказальнымі вершамі гэтага тыпу з'яўляюцца «Вячорная містэрыя» (1932), «Вячорны абразок» (1924), «У небе палаюць чырвоныя хмары...» (1922), «Новая зіма» (1933), «Незгаданае» (1934). У іх выяляўецца па-майстэрску выпісаны арсеннеўскі начны свет, які ствараюць гарачыя колеры неба, чырвоныя рабіны, залатыя пшанічныя палеткі. Частымі элементамі начной паэтычнай карціны Н. Арсенневай з'яўляюцца іскрыстыя зоркі і месяц-вартаўнік. Зорка ўвасабляе сабой паспяховасць, надзею, шчасце, неўміручасць, наканаванне. Месяц - гэта вока ночы, апякун сонных мараў, тугі, пачуццяў і думак, закуты ў срэбра зброі pbuар // - вартуе места й нас да дня (221). Ён сімвал тайных, невядомых бакоў прыроды, як нямы сведка ӱважліва наглядае за чалавекам і яго ўчынкамі. Месяц можа сваім ясным святлом разагнаць глыбокі змрок, раскрыць тайніцы ночы, а тым самым вызваліць чалавека з трывогі. Месяц Арсенневай «круглаваты, зялёна-сіні», «мокpы $i$ срэбны»), «бельl», «сиюдзённы $i$ чьлстыљ», маляўніча «прыбраны y імглу», сплятае «прывабныл сеці», а зоры нібыта «вочьи мальх засмучаных анёлай», «смяюииа праз слёзы». Гэтыя два элементы начнога краявіду бачацца невыпадковымі ў паэзіі Арсенневай. Яны выступаюць як сімвалы надзеі вярнуцца на родную зямлю - па зорах

5 Ст. Станкевіч, Аб беларускай літаратурнай сучаснасьиі ў Заходняй Беларусі, «Нёман», 1932, кн. 5, с. 168, 169. 
можна ж вызначыць дарогу на Радзіму, а месяц асветліць гэты шлях. Вячэрні і начны пейзаж Арсенневай - гэта рознаколерныя, насычаныя шматлікімі фарбамі і адценнямі жывапісныя карціны, дзе дамінуюць каралеўскія колеры - чырвань і золата. Летняя ноч у вершах паэтэсы захапляе сваім злоўленым па-жаночаму хараством, чараўнічасцю і месцамі як бы сваёй дэманстратыўнай асацыяльнасцю. Н. Арсеннева выдатна валодае каляровай палітрай, што забяспечвае стварэнне карціны маляўнічага роднага вячэрняга краявіду:

Сплёў вечар вянок прамяністы

3 шыпшыны і макаў чырвоных,

у небе павесіў прачыстым, на ясных нябёсных загонах...

А сонцу вянок спадабаўся,

у чырвані сонцу да твару...

Так - захад у фарбы прыбраўся, так вечар заняўся пажарам.

Усё, што такім было знаным, адразу зрабілася дзівам:

настольнікам, золатам тканым, паслаліся жытнія нівы, агнём загарэліся стрэхі, сады і вяршаліны бору, і густа праз хмараў узрэхі сыпнулі, як зерняты, зоры (57).

Вятраны змрок... Старыя вербы над рэчкай пранікамі пяраць па шэрай воднай палатніне.

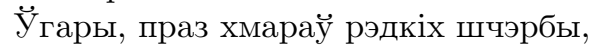
зіркае месяц круглатвары, зялёна-сіні (72).

Вобраз зімовай ночы ствараецца ў вершы «Ціха плыў месяц» (1921). Але і цяпер, як і $\breve{y}$ летнюю пару, у прыродзе гаспадараць лагода і хараство, якія выклікаюць ў лірычнай гераіні самыя пазітыўныя эмоцыі, уражанні, бо Прырода i, відаць, тая ж Ноч, як той лекар, аздарайляе душу, дапамагае дараваць крьйды, вярнуць адчуванне хараства жыция, яго многалучнасиі, аптылмізм, актуалізуе духоўнья i фізічныля сіль лірычнага персанажа, жаданне рэалізаваць мары $і$ памкненні ${ }^{6}$ I таму арсеннеўская лірычная гераіня верша шчаслівая, яна

6 В. Я. Зарэцкая, М. І. Яніцкі, Гендэрнае светаразуменне ў паэзіi Наталіi Арсенневай, [y:] Гуманістычны пафас заходнебеларускай літаратуры: манаграфія, Брэст 2007, с. 36 . 
адчувае прыліӱ новых жыццёвых сіл, фізічную і псіхічную дужасць, якія хоча бескарысліва скіраваць на паляпшэнне навакольнага свету, жыцця людзей:

Долі пайшла б паляваць далёка

я для зямліцы, што сьпіць без прасьвету,

і разьліла б, як сягнуць можа вока,

шчасьце над белым, асьнежаным сьветам (17).

Пад знакам прыроднай цішыні, маўчання адбываюцца несупынныя змены ў прыродзе, у настроі7:

Сыплюцца з клёнаў лісты, сыплюцца ціха, маўкліва, крыюць зямлю і кусты пражаю жоўтай, шасьцівай (19).

Ды час змяркання, вечару і начная пара выклікаюць у Н. Арсенневай тугу, тое пачуццё, якое ішло побач з паэтэсай амаль усё жыццё і якое паглыбляецца пад уплывам успамінаў пра родныя краявіды бацькаўшчыны, якія запісаліся $\ddot{y}$ яе памяці $\ddot{y}$ часы, калі магла яшчэ хадзіць па зялёных нівах сваёй радзімы, купацца ў промнях яе сонца, слухаць спевы родных птушак. Пачуццё тугі мучыць яе душу, ад яго немагчыма дзесьці схавацца:

Не уццячы ад тугі. (Залацістыя сеці ясны вечар накінуў на нівы й лугі.) Затрымаліся, у вышу ня хочуць ляцеці мае думкі крылатыя, дзеці (31)

для тугі няма адлежнасьцяў, ні часу: усюды і заўжды яна із намі, тут! (138)

Трэба сказаць, што ў начной прасторы вершаў Арсенневай выяўляюцца вобразы двух гарадоў, два кантрастныя краявіды, якія выклікаюць у паэтэсы, несумненна, наплыў розных пачуццяй і паміж якімі разыгрываецца своеасаблівая бітва. 3 аднаго боку, стаіць любімы горад роднай Маці-Беларусі, з другога - эмацыянальна чужы для Арсенневай горад Амерыкі. Першы вобраз выклікае ў свядомасці паэтэсы

7 А. Петрушкевіч, Шляхі ў паэзіі Наталлі Арсенневай і Максіма Танка, "Studia Wschodniosłowiańskie", Białystok 2006, t. 6, s. 103. 
тое ж пачуццё тугі, якое не адпускала яе ӱ час першай разлукі з радзімай, калі прыйшлося сям'і Н. Арсенневай жыць ў Хэлмне на Памор'і:

Сонца заходзіць... На вежах кляшторных

скрозь загараюцца тысячы зорных

зырка-чырвоных агнёў...

Хораша... Сэрца-ж міжвольна імкнецца

ў край, што яшчэ харашэйшым здаецца, родны, найлепшы з краёў.

Там... Там усё быццам так, а іначай

хваляй у сэрца ліецца гарачай, там... Там усё мне мілей (27).

У вершы «Родны край» з 1924 года, а таксама ў пазнейшым («Вечар у Вільні», 1944), малюецца вобраз дарагой яе сэрцу Вільні, схаванай у чёмныл тумане ночы. I тут Ноч абвастрае пачуцці любові да свайго любімага горада, бестурботнага дзяцінства, аазіса спакою у маладыя гады з глыбокай вечаровай цішшу, калі не спіиь яшчэ малая кавярня. Усё тут, кожная вуліца, кожны завулак, так блізкія сэрцу паэтэсы, усё так добра знаёмае, мілае аж да самазабыцця. Менавіта тут начною парою, па-лермантаўску, марыцца Арсенневай развітацца са светам, каб адысці ӱ вечнасць:

Манюся тут сваю апошнюю зару

я сустракаць,

адсюль -

пайсьці адвечным шляхам (133).

А горад у чужой Амерыцы не выклікае ў Арсенневай ніякіх пазітыўных эмоцый («Меставы вечар», «Сон»). Ён для яе ў найлепшым выпадку абыякавы, шэры, а то і цалкам адчужэлы сваім ненатуральным шумам і рытмам.

$$
\begin{aligned}
& \text { Шуміць, гудзе, грыміць } \\
& \text { вялізны молах - горад, } \\
& \text { нат найдзічэйшы джаз } \\
& \text { такі ня выб’е рытм }(274) \text {. } \\
& \text { А мне хочацца такое цішы, } \\
& \text { Якое тут няма, } \\
& \text { А толькі ў нас (215). }
\end{aligned}
$$

У еўрапейскай паэзіі, асабліва ў перыяд рамантызму, вечар і ноч паказваюцца майстрамі слова як час маўклівы, змрочны, трывожны, 
напойнены драматычнай цішынёй, які выклікае ў свядомасці чалавека маркотныя перажыванні і думкі. Паэзія Н. Арсенневай таксама не пазбаўлена паказу такога вобразу вечара і ночы. Вершы гэтага тыпу напісаны паэтэсай якраз у найбольш трывожныя часы Другой сусветнай вайны. У ix няма ранейшага прыгожага начнога краявіду, y ix ноч раскрывае усё тое нялюдскае, што вайна прынесла людзям:

Дзень гас цьмяным агнём прыкручанай газьніцы..

$(\ldots)$

А ўсюды -

тут і там - ня хвояў верхавіны,

ня спаленыя пні - ваенным днём даніны -

запраўдныя крыжы растуць уздоўж дарог.

Пад крыжам, без крыжа, падцятаю галінай

на жорсткі, гойстры жвір спаць ці адзін прылёг... (82)

У час вайны ноч спалучаецца па агульнай асацыяцыі з восенню і яе цемраю. Яны ствараюць новае арсеннеўскае трыадзінства. Палітра верша цямнее:

Спраўляюць восень, ноч і цемра глухі, распачны фэстываль (71).

Менавіта гэты час Другой сусветнай вайны быў асабліва цяжкім для маладых дзяўчат і жанчын, мужчыны якіх апынуліся на вайне. Ix Ночы сталі ияпер дойгія, чорныля. Арсеннеўская лірычная гераіня таго часу $\breve{y}$ начной прасторы адчувае сябе самотнай, жыве $\breve{y ~ р о с п а ч ы ~}$ па страце каханага, мужа. Аднак успаміны аб радасных ранейшых $n a$ хучьх чаромхавых ночах суцішаюць яе ўнутраны боль. Яна, як і раней, жыве надзеяй, што кожная ноч калісьці закончыцца, надыдзе сонечны дзень і гора праміне:

Ці сяньня будзе гэта, ці тады, калі ўжо зложым крылы ня нам гадаць, але зьляціць калісь бяду скасіць Ярыла!

На край зньямоглы, на людзей сыпне ён сонечныя стрэлы (97).

Аднак ранейшая эстэтызацыя прыродных з'яў, у прыватнасці вечара і ночы, з цягам часу выразна заціхае $\ddot{y}$ творчасці Наталлі Ар- 
сенневай. Развітаўшыся назаўсёды з Радзімай, яна не можа быць узбоч нацыянальных праблем, і $\ddot{y}$ яе вершы рашуча ўваходзяць пытанні этычнага характару, і яны перабудойваюць лірычны настрой «арсеннеўскіх» твораў - «чыстая краса» родных малюнкай і часткова замежных пейзажаў усё болей насычаецца ідэйна-маральнай падсветкай. Ды з поўным правам можна сказаць, што, як зоркі начной парою асвятляюць зямлю, так вершы паэтэсы ўпрыгожваюць беларускую літаратуру.

\section{S T R E S Z C Z E N I E}

\section{TEMAT WIECZORU I NOCY W TWÓRCZOŚCI NATALII ARSIENNIEWEJ}

Białoruska poetka emigracyjna Natalia Arsienniewa znana jest w literaturze przede wszystkim jako „miłośniczka rodzimej przyrody”, „poetka jesieni”. W artykule zwrócono uwagę na jeszcze jeden istotny fakt, mianowicie na to, że Arsienniewa to także „poetka pory wieczorowej”, nadzwyczajna „malarka nocy”. Zafascynowanie nocnym pejzażem jest widoczne już w jej pierwszych wierszach i nie gaśnie wraz z upływem lat. Noc Arsienniewej, w odróżnieniu od tradycyjnego jej ukazania, nie jest ciemna i mroczna, wręcz przeciwnie, zachwyca swym pięknem i wielobarwnością. Nieodłącznymi elementami nocnego krajobrazu poetki są księżyc i gwiazdy. Ponadto noc dla Arsienniewej to czas refleksji, przemyśleń, marzeń.

Słowa kluczowe: białoruska poetka emigracyjna, temat wieczoru i nocy, egzystencja, Ojczyzna, pejzaż nocny, gwiazdy, księżyc.

\section{S U M M A R Y}

\section{EVENING AND NIGHT IN NATALYA ARSENEVA'S POETRY}

In literature Belarusian emigrant poetess Natalya Arseneva is famous for her love to native nature and autumn. The article discusses another crucial fact Arseneva is a poetess of evening and night. Her fascination with night landscape observed in her first poems can be found in her entire creation process. Arseneva's night is neither dark nor gloomy. On the contrary, the night excites by its beauty and multicolor. The moon and stars are an inseparable element of the night landscape. For Arseneva night is the time of reflection and dreams.

Key words: Belarusian emigrant poetess, subject of night and evening, existence, homeland, night landscape, stars, moon. 